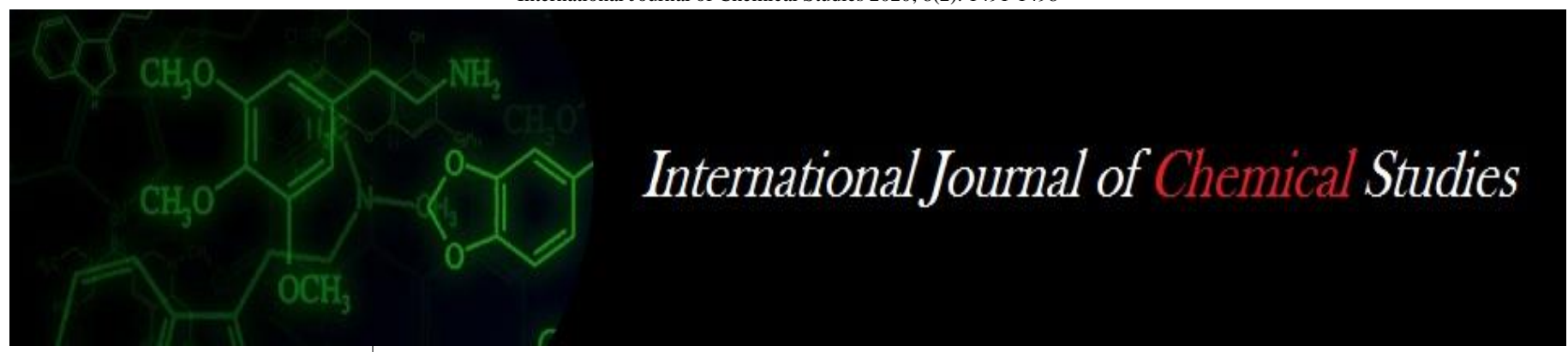

P-ISSN: 2349-8528

E-ISSN: 2321-4902

www.chemijournal.com

IJCS 2020; 8(2): 1491-1498

(C) 2020 IJCS

Received: 07-01-2020

Accepted: 09-02-2020

\section{G Sashikala}

Department of Soil Science and

Agricultural Chemistry, S.V.

Agricultural College, Acharya N.G

Ranga Agricultural University,

Tirupati, Andhra Pradesh, India

\section{MVS Naidu}

Department of Soil Science and Agricultural Chemistry, S.V.

Agricultural College, Acharya N.G.

Ranga Agricultural University,

Tirupati, Andhra Pradesh. India

\section{KV Ramana}

Department of Soil Science and

Agricultural Chemistry, S.V.

Agricultural College, Acharya N.G.

Ranga Agricultural University,

Tirupati, Andhra Pradesh, India

KV Nagamadhuri

Department of Soil Science and

Agricultural Chemistry, S.V.

Agricultural College, Acharya N.G.

Ranga Agricultural University,

Tirupati, Andhra Pradesh, India

\section{A Pratap Kumar Reddy}

Department of Soil Science and

Agricultural Chemistry, S.V.

Agricultural College, Acharya N.G.

Ranga Agricultural University,

Tirupati, Andhra Pradesh, India

P Sudhakar

Department of Soil Science and

Agricultural Chemistry, S.V.

Agricultural College, Acharya N.G.

Ranga Agricultural University,

Tirupati, Andhra Pradesh, India

\section{Nageswar Reddy}

Assistant Professor in Chemistry, GDC, Puttur, Andhra Pradesh, India

\section{Characterization and classification of soils in upland soils of Tatrakallu village of Anantapuramu district in Andhra Pradesh}

\author{
G Sashikala, MVS Naidu, KV Ramana, KV Nagamadhuri, A Pratap \\ Kumar Reddy, P Sudhakar and C Nageswar Reddy
}

DOI: https://doi.org/10.22271/chemi.2020.v8.i2w.8972

\begin{abstract}
Nine typical pedons representing upland landforms in semi-arid ecosystem of Tatrakallu village, Anantapuramu district of Andhra Pradesh originated from granite-gneiss parent material were studied for their morphological, physical and chemical properties, soil genesis, taxonomy and nutrient status. The soils were slightly acidic to strongly alkaline (6.6 to 8.3$)$ in reaction, non-saline $\left(0.02\right.$ to $\left.0.16 \mathrm{dSm}^{-1}\right)$ shallow, deep and very deep in depth and had isohyperthermic temperature and ustic soil moisture regimes. The texture, organic carbon (OC), cation exchange capacity (CEC) and base saturation were ranged from loamy sand to sandy clay loam, 1.0 to $5.5 \mathrm{~g} \mathrm{~kg}^{-1}, 7.6$ to $21.1 \mathrm{cmol}(\mathrm{p}+) \mathrm{kg}^{-1}$ and 55 to 98 per cent, respectively. The soils were low (65 to $195 \mathrm{~kg} \mathrm{ha}^{-1}$ ) in available nitrogen, low to high (1.2 to 77.9 $\mathrm{kg} \mathrm{P}_{2} \mathrm{O}_{5} \mathrm{ha}^{-1}$ ) in available phosphorous and potassium (35 to $521 \mathrm{~kg} \mathrm{~K}_{2} \mathrm{O} \mathrm{ha}^{-1}$ ), deficient to sufficient (6.2 to $44.7 \mathrm{mg} \mathrm{kg}^{-1}$ ) in available sulphur, deficient in DTPA extractable $\mathrm{Zn}$, deficient to sufficient in DTPA extractable Fe and Mn and sufficient in DTPA extractable $\mathrm{Cu}$. Pedons, 1, 2, 3, 4, 5, 8 and 9 were placed under Entisols due to absence of sub-surface diagnostic horizon and were classified as Lithic Ustorthents whereas pedon 6 was grouped under Inceptisols due to presence of cambic (Bw) sub-surface diagnostic horizon and classified as Typic Haplustepts. However, Pedon 7 was classified under Alfisols due to presence of argillic horizon (Bt) as Lithic Haplustalfs.
\end{abstract}

Keywords: Characterization, cambic horizon, argillic horizon, Entisols, Inceptisols, Alfisols

\section{Introduction}

Soils are one of the important natural resources which produces, food, fibre and fodder, the basic needs of our existence. In quest for augmenting agricultural production for meeting the varied demands of the increasing population, over exploitation and unscientific management of soil resources without any perception of long term sustainability have not only caused adverse impact on productivity and growth rate in agriculture but also resulted in marked resource degradation along with serious environmental problems (Reddy and Naidu, 2016). Characterization and classification of soils for different land uses is the first milestone to develop database for formulating land use models. Systematic study of morphology and taxonomy of soils provides information on nature and type of soils, their constraints, potentials, capabilities and their suitability for various uses (Sekhar et al. 2014) [13]. Characterization helps in determining the soil potentials and identifying the constraints in crop production besides giving detailed information about different soil properties. Soil classification, on the other hand, helps to organize our knowledge and facilitates the transfer of experience and technology from one place to another and helps to compare soil properties. The coupling of soil characterization and soil classification is a powerfool tool for development of management strategies for food security and environment sustainability.

Anantapuramu is the largest district of Andhra Pradesh and second driest part of the country after Jaisalmer in Rajasthan (APSAC, 2018) ${ }^{[2]}$. The district of Anantpuramu is chronically drought-affected especially, Vajrakarur mandal and in particular Tatrakallu village (Naidu et al. 2008) ${ }^{[7]}$. Tatrakallu village in Anantapuramu district of Andhra Pradesh is pre-dominantly under rainfed farming with erratic rainfall distribution (APSAC, 2018) ${ }^{[2]}$ associated with low crop productivity and needs site-specific information in terms of soil characteristics, their 
potentials and limitations for soil resource development and management hence, the present investigation was carried out.

\section{Materials and Methods}

The study area, Tatrakallu village is located in Anantapuramu district of Andhra Pradesh. Tatrakallu village lies in between $14^{\circ} 58^{\prime}$ to $15^{\circ} 00^{\prime} \mathrm{N}$ latitudes and $77^{\circ} 19^{\prime}$ to $77^{\circ} 25^{\prime} \mathrm{E}$ longitudes with a spatial extent of 2469.29 ha (Fig.1). The village comprises of one hamlet namely Nakka Nukina palli Thanda (NNP Thanda). The study area comes under the Scarce Rainfall zone of Andhra Pradesh. The soils of Tatrakallu village were developed from granite-gneiss and limestone / shale. The climate of the study area was semi-arid monsoonic with distinct summer, winter and rainy seasons. The mean annual rainfall recorded in the last 10 years (2009 to 2018) was $528.40 \mathrm{~mm}$ of which $92 \%$ was received during May to November months. The mean annual temperature was $33.03{ }^{\circ} \mathrm{C}$ with a mean summer temperature of $40.5{ }^{\circ} \mathrm{C}$ and mean winter temperature of $26.13{ }^{\circ} \mathrm{C}$. The maximum temperature recorded for the last ten years was $38.4{ }^{\circ} \mathrm{C}$ and the minimum temperature was $17.2{ }^{\circ} \mathrm{C}$ in the months of April and November, respectively. The soil moisture regime has been computed as ustic and soil temperature regime as isohypertherrmic. A detailed soil survey was conducted using 1:10,000 scale base map as per the procedure outlined by AIS \& LUS, (1970) [1]. Auger bores, mini pits, road cuts and pedons located on plains and uplands were studied. The detailed morphological description of these nine pedons were studied in the field as per the procedure outlined in Soil Survey Manual (Soil Survey Division Staff, 2015) ${ }^{[19]}$. Horizon-wise soil samples were collected and analyzed for important physical and chemical properties by standard procedures (Jackson, 1973) ${ }^{[4]}$ and studied for their genesis. The soils were classified according to Keys to Soil Taxonomy (Soil Survey Staff, 2014) ${ }^{[20] .}$

\section{Results and Discussion \\ Soil morphology}

The detailed morphological characteristics of the soils were presented in Table 1. The depth of soil varied from shallow to deep in depth, well drained. The soil colour varied from 5.0 YR to 10 YR. The variation in soil colour appears to be the function of chemical and mineralogical composition as well as textural makeup of soils and conditioned by topographic position and moisture regime (Sireesha and Naidu, 2013) ${ }^{[18]}$. The soils of Tatrakallu showed wide textural variation and the texture was loamy sand, sandy loam, sandy clay loam and silty clay loam. P6 showed strong to violent effervescence while all the pedons exhibited no effervescence with dilute $\mathrm{HCl}$ indicating abscence of $\mathrm{CaCO}_{3}$ in those pedons. The pedons located in uplands showed single grain, sub-angular blocky and angular blocky structure (Sharma et al. 2004) ${ }^{[16]}$. The consistence in pedons of uplands was loose to hard (d), loose to firm (m) and non-sticky and non-plastic to sticky and plastic (w). Pedons located in uplands showed no diagnostic horizon (P1, P2, P3, P4, P5, P8 and P9), argillic (Bt) horizon (P15) and cambic (Bw) horizon (P6) were classified under Entisols, Inceptisols and Alfisols. Pedons exhibited clear and smooth boundary in surface horizons and diffuse and wavy boundary in sub-surface horizons.

\section{Physical characteristics}

The detailed physical characteristics of the soils were presented in Table 2. Particle size analysis revealed that the clay content varied from 8.3 to 35.8 per cent. The enrichment of clay in Bss horizon of pedon 6 was primarily due to in situ weathering of parent material. Sharma et al. (2004) [16] observed an increase in clay content in sub-surface horizons as compared to surface horizons in soils of Neogal watershed in north-west Himalayas. The increasing trend of clay with depth was primarily due to vertical migration of clay (Vedadri and Naidu, 2018) ${ }^{[22]}$. Silt fraction ranged from 4.0 to 49.7 per cent. The irregular distribution of silt with depth might be due to variation in weathering of parent material or in situ formation. Similar results of irregular trend with depth were also reported by Kumar and Naidu, (2012) ${ }^{[5]}$ in soils of Vadamalpeta mandal in Chittoor district of Andhra Pradesh. The sand content ranged from 19.3 to 85.9 per cent. Higher sand content was observed in surface horizons than those of sub-surface horizons, which was opposite to clay content and was due to surface impoverishment of finer particles by runoff water.

Bulk density in different horizons of pedons ranged between 1.17 to $2.56 \mathrm{Mg} \mathrm{m}^{-3}$ which gradually increased with depth due to the presence of low organic matter and compaction of soil aggregates down the profile (Singh and Agrawal, 2005). Particle density of different pedons ranged from 2.40 to 2.83 $\mathrm{Mg} \mathrm{m}^{-3}$. The values of water holding capacity varied from 20.0 to 55.3 per cent. Pedons 1, 5, 6 and 9 showed a decreasing trend with depth whereas pedons 3 and 7 exhibited an increasing trend with depth. These differences in water holding capacity values were due to variation in the depth, clay, silt and organic carbon content of the pedons. These results match with those of Vedadri and Naidu, (2018) in soils of Chillakur mandal in Nellore district of Andhra Pradesh.

\section{Chemical characteristics}

The chemical characteristics of the soils are presented in Table 3. The $\mathrm{pH}$ of the soils ranged from 6.6 to 8.3. This wide variation in $\mathrm{pH}$ of Tatrakallu village soils was attributed to the nature of the parent material, leaching, presence of calcium carbonate and exchangeable sodium. Similar views were expressed by Reddy and Naidu, (2016) ${ }^{[9]}$ in Chennur mandal of Kadapa district in Andhra Pradesh. The increasing trend of $\mathrm{pH}$ with depth might be due releasing of organic acids during decomposition of organic matter and these acids might have brought down the $\mathrm{pH}$ in the surface soils.

The electrical conductivity (EC) in soils of Tatrakallu village was ranged from 0.02 to $0.16 \mathrm{dS} \mathrm{m}^{-1}$, indicating that the soils in study area were non-saline. The low EC in these soils was due to leaching of soluble salts by percolating water. Organic carbon (OC) content was low to medium ranging from 1.0 to $5.5 \mathrm{~g} \mathrm{~kg}^{-1}$ (Table 3). Almost all the pedons showed a decreasing trend in OC with depth which could be attributed to the fact that the surface horizons showed more organic matter content than sub-surface horizons due to the addition of plant residues and farmyard manure in surface horizons. Low OC in the soils might be attributed to the prevalence of tropical conditions, where the degradation of organic matter occurs at a faster rate coupled with low vegetative cover, there by leaving less OC in the soils (Satish et al. 2018) ${ }^{[11]}$.

The CEC in all the pedons estimated by ammonium acetate extract varied from 7.6 to $21.1 \mathrm{c} \mathrm{mol}(\mathrm{p}+) \mathrm{kg}^{-1}$ soil. Relatively low CEC in the study area might be due to dominance of clay minerals with low CEC and presence of hydrous oxides of $\mathrm{Fe}$ and $\mathrm{Al}$ (Sarkar et al. 2002) ${ }^{[10]}$. The free $\mathrm{CaCO}_{3}$ ranged from 0.5 to $17.3 \%$. However, in pedons 1,3 and 7 the $\mathrm{CaCO}_{3}$ increased with depth which might be due to downward movement of calcium and its subsequent precipitation as carbonate and / or decomposition of calcium carbonate 
whereas the pedons 6 and 8 showed a decreasing trend with depth. The remaining pedons did not show any particular trend with depth, this may either be due to variable nature of geological material that contributed to these soils or due to rapid leaching of carbonates (Sahrawat, 1999) [12]. Exchangeable bases in all pedons were in the order of $\mathrm{Ca}^{2+}>$ $\mathrm{Mg}^{2+}>\mathrm{Na}^{+}>\mathrm{K}^{+}$and $\mathrm{Ca}$ being the dominant cation on the exchange complex. The base saturation varied from 55 and 98 $\%$. The higher base saturation observed in almost all pedons might be due to higher amount of $\mathrm{Ca}^{2+}$ occupying exchange sites on the colloidal complex. The differences in base saturation indicated the degree of leaching. The variation in base saturation of the soils might also be due to variation in nature and / or content of soil colloids and relatively high base saturation in surface layer could be attributed to the recycling of basic cations through vegetation (Devi et al. 2015). The narrower $\mathrm{Ca}^{2+} / \mathrm{Mg}^{2+}$ ratio was due to suppression of $\mathrm{Ca}$ solubility, substitution of $\mathrm{Mg}^{2+}$ or $\mathrm{Ca}^{2+}$ by plants and recycling of unusual amount of $\mathrm{Mg}$ (Sharma et al. 2011) ${ }^{[14]}$.

\section{Soil genesis}

The examination of soil profiles showed distinctive horizontal layers, some of which were highly visible. Significant changes occurred as the soils were developed from relatively unconsolidated parent material. Pedons 1, 2, 3, 4, 5, 6, 7, 8 and 9 were developed form granite-gneiss. In the Tatrakallu village, the addition of organic matter was noticed due to accumulation of organic matter and humus on the surface soils and to certain depth of sub-soil in all the pedons of the study area. Higher organic matter in the surface soils was due to addition of organic matter through leaf fall, stubbles, roots and organic manures restricting to the surface soils only (Satish et al. 2018) [11]. Further, the organic carbon was leached to lower layers along with percolating water leading to its loss from the surface soils. Another method of soil formation was translocation of material from one point to another within the soil. The development of B horizons in pedon 7 was a result of illuviation and eluviation. Due to these processes the argillic horizon $(\mathrm{Bt})$ was formed. Next category of soil forming process was the transformation of minerals and organic substances within the soil. The colour and structure get transformed in the sub-soil leading to the development of cambic (Bw) horizon in pedon 6. However, processes such as eluviation and illuviation were not operated in the pedons $1,2,3,4,5,6,7,8$ and 9 . Hence, they don't exhibit soil development in sub surface horizons. The interplay of climate, topography and vegetation acting on parent material over a period of time resulted in the development of different soils viz., Entisols, Inceptisols and Alfisols in uplands of Tatrakallu village in Anantapuramu district of Andhra Pradesh.

\section{Soil classification}

Based on the morphological characteristics, physical and chemical properties of the typifying pedons, the soils were classified up to family level (Soil Survey Staff, 2014) ${ }^{[20]}$. Pedons 1, 2, 3, 4, 5, 6, 7, 8 and 9 showed no diagnostic sub surface horizon and were placed under Entisols order whereas pedon 6 which have cambic (Bw) sub-surface diagnostic horizon only were classified under Inceptisols. Pedon 7 have argillic (Bt) sub surface diagnostic horizon which were classified under Alfisols. Pedon 6 was grouped under Ustepts at sub-order level due to presence of ustic soil moisture regime and Haplustepts at greatgroup level because these pedons did not have either duripan or calcic horizon and base saturation was more than $60 \%$ at a depth between 0.25 to 0.50 $\mathrm{m}$ from the surface. However, pedon 6 did not exhibit any intergradations with other taxa or an extra gradation from the central concept. Hence, these pedons were logically classified as Typic Haplustepts. Pedon 7 was grouped under Ustalfs at sub-order level due to presence of ustic soil moisture regime and Haplustalfs at great group level because these pedons did not have either duripan or calcic horizon and base saturation was more than $60 \%$ at a depth between 0.25 to $0.50 \mathrm{~m}$ from the surface. Pedon 7 was placed under Lithic Haplustalfs at subgroup level due to the presence of lithic contact within 50 $\mathrm{cm}$ of the mineral soil surface.

\section{Nutrient status}

Macronutrients: Soil fertility exhibits the status of different soils with regard to the amount and availability of nutrients essential for plant growth (Table 4). The available $\mathrm{N}$ content varied between 65 and $195 \mathrm{~kg} \mathrm{ha}^{-1}$ soil and these soils were low in available nitrogen. The available nitrogen was found to be maximum in the surface horizons and decreased more or less with depth in all the pedons, which might be due to decreasing trend of organic carbon with depth. In general low available $\mathrm{N}$ status in these soils might be due to the fact that, semi-arid condition of the area might have favoured rapid oxidation and lesser accumulation of organic matter, releasing more $\mathrm{NO}_{3}^{-}-\mathrm{N}$ which could have been lost by leaching (Kumar and Naidu, 2012) ${ }^{[5]}$.

The available phosphorus varied from 1.2 to $77.9 \mathrm{~kg} \mathrm{P}_{2} \mathrm{O}_{5} \mathrm{ha}^{-1}$ soil. The lower phosphorus content was observed in red soils which could be attributed to the fixation of released phosphorus by kaolinite. The higher available phosphorus was observed in the surface horizons and decreased regularly with depth. The reason for higher available phosphorus in surface horizons might possibly be due to the confinement of crop cultivation to the rhizosphere and supplementing the depleted phosphorus by external sources (Reddy and Naidu, 2016) ${ }^{[9]}$ and also due to indiscriminate use of phosphorus containing complex fertilizers.

The available potassium in different soils ranged from 35 to $521 \mathrm{~kg} \mathrm{ha}^{-1}$ soil. The highest available $\mathrm{K}_{2} \mathrm{O}$ content was observed in surface horizons and showed more or less decreasing trend with trend. This might be attributed to more intense weathering, release of labile $\mathrm{K}$ from organic residues, application of $\mathrm{K}$ fertilizers and upward translocation of $\mathrm{K}$ from lower depths along with capillary rise of ground water. Similar findings were observed by Satish et al. (2018). The available $S$ in study area varied between 6.2 and $44.7 \mathrm{mg} \mathrm{kg}^{-1}$ soil and these soils were deficient to sufficient in available sulphur. Surface layers contained almost more available sulphur than sub-surface layers which could be due to higher amount of organic matter in surface layers than in sub-surface layers (Rao et al. 2008) ${ }^{[8]}$.

Micronutrients: The DTPA extractable zinc ranged from 0.07 to $0.54 \mathrm{mg} \mathrm{kg}^{-1}$ soil (Table 6). Vertical distribution of $\mathrm{Zn}$ exhibited little variation with depth. Considering $0.60 \mathrm{mg} \mathrm{kg}^{-1}$ as critical level (Lindsay and Norvell, 1978) ${ }^{[6]}$ these soils were deficient in available $\mathrm{Zn}$. The low available $\mathrm{Zn}$ was possibly due to high soil $\mathrm{pH}$ values which might be resulted in the formation of insoluble compounds of $\mathrm{Zn}$ or insoluble calcium zincate (Vedadri and Naidu, 2018) ${ }^{[22]}$.

All the pedons were found to be sufficient in available $\mathrm{Cu}$ ( 0.25 to $1.90 \mathrm{mg} \mathrm{kg}^{-1}$ soil) as all the values were above critical limit of $0.20 \mathrm{mg} \mathrm{kg}^{-1}$ soil as suggested by Lindsay and Norvell, (1978) ${ }^{[6]}$. The DTPA extractable Fe content varied 
from 0.52 to $22.04 \mathrm{mg} \mathrm{kg}^{-1}$ soil. According to critical limit of $4.5 \mathrm{mg} \mathrm{kg}^{-1}$ of Lindsay and Norvell, (1978) ${ }^{[6]}$, the soils were deficient to sufficient in available Fe. The surface horizons contain more Fe than sub-surface horizons. It might be due to accumulation of organic carbon in the surface horizons. The organic carbon due to its affinity to influence the solubility and availability of iron by chelation effect might have protected the iron from oxidation and precipitation, which consequently increased the availability of iron (Thangasamy et al. 2005) ${ }^{[21]}$.
Available manganese content varied between 3.62 and 38.88 $\mathrm{mg} \mathrm{kg}{ }^{-1}$ soil. According to critical limit of $1.0 \mathrm{mg} \mathrm{kg}^{-1}$ of Lindsay and Norvell, (1978) ${ }^{[6]}$, the soils were sufficient in available $\mathrm{Mn}$ and almost decreased with depth which might be due to higher biological activity and organic carbon in the surface horizon. Similar findings were also made by Sireesha and Naidu, (2013) ${ }^{[18]}$ in soils of Chennur mandal of Kadapa district.

Table 1: Summary of the morphological characters of the pedons

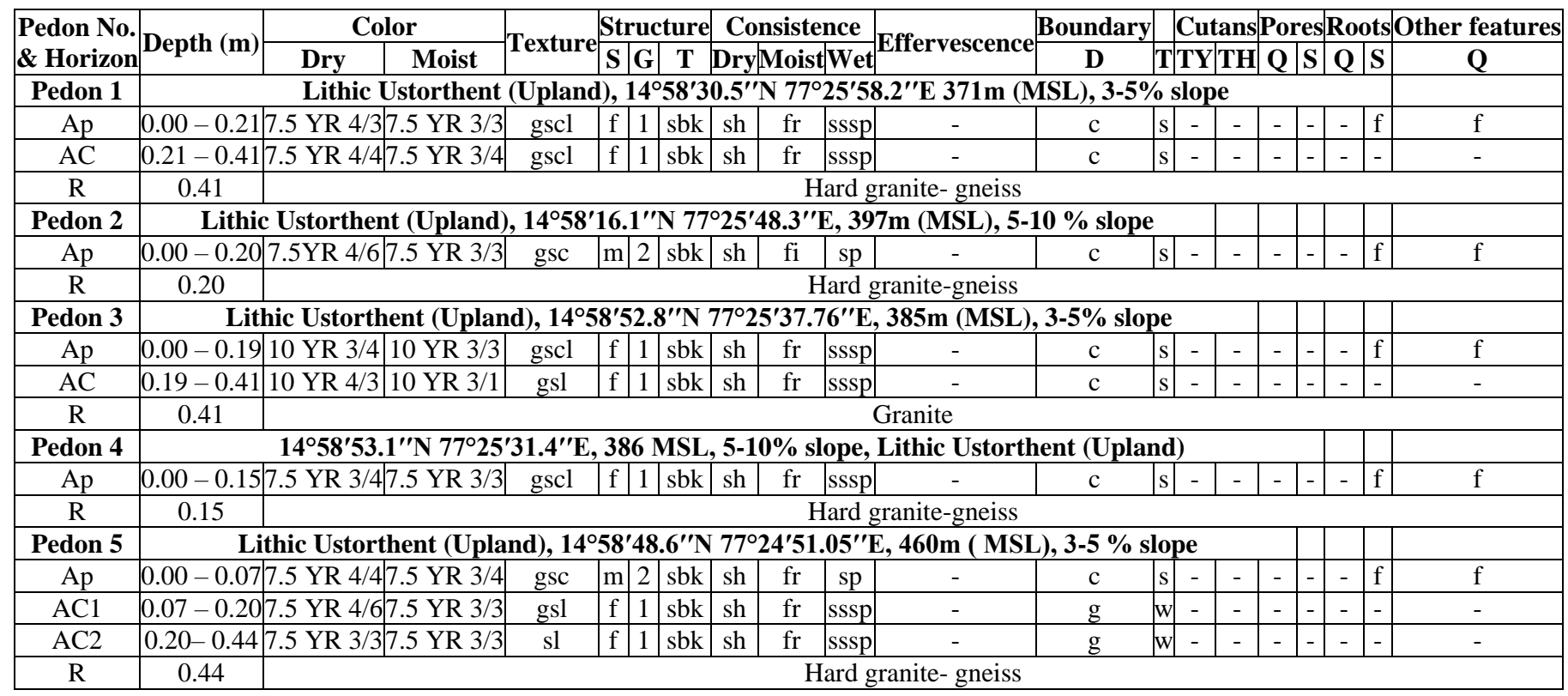

\begin{tabular}{|c|c|c|c|c|c|c|c|c|c|c|c|c|c|c|c|c|c|c|}
\hline \multirow{2}{*}{$\begin{array}{l}\text { Pedon No. } \\
\text { \& Horizon }\end{array}$} & \multirow{2}{*}{ Depth (m) } & \multicolumn{2}{|c|}{ Color } & \multirow{2}{*}{ Texture } & \multicolumn{5}{|c|}{ Structure Consistence } & \multirow{2}{*}{ Effervescence } & \multicolumn{2}{|c|}{ Boundary } & \multicolumn{3}{|c|}{ Cutans } & \multicolumn{2}{|c|}{ Pores Roots } & \multirow{2}{*}{ Other features } \\
\hline & & Dry & Moist & & \begin{tabular}{|l|l|l}
$\mathbf{S}$ & $\mathbf{G}$ \\
\end{tabular} & $\mathbf{T}$ & Dry & Iois & tWet & & D & $\mathbf{T}$ & TY & TH & $\mathbf{Q} \mid \mathbf{S}$ & \begin{tabular}{l|l|l}
$\mathbf{S}$ & $\mathbf{Q S}$ \\
\end{tabular} & $\mathbf{S} \mathbf{Q}$ & \\
\hline Pedon 6 & \multicolumn{18}{|c|}{ Typic Haplustept (Upland), $14^{\circ} 59^{\prime} 31^{\prime \prime} 1^{\prime \prime} 7^{\circ} 23^{\prime} 33.3^{\prime \prime} \mathrm{E}, 434 \mathrm{~m}$ (MSL), 1-3 \% slope } \\
\hline Ap & $0.00-0.22$ & 10 YR $8 / 2$ & $10 \mathrm{YR} 6 / 2$ & gsicl & $\mathrm{m} 2$ & sbk & sh & fi & $\mathrm{sp}$ & ev & $\mathrm{c}$ & $\mathrm{s}$ & - & \begin{tabular}{|l|}
- \\
\end{tabular} & \begin{tabular}{|l|l}
- & - \\
-
\end{tabular} & \begin{tabular}{l|l|}
- & - \\
\end{tabular} & f & \\
\hline $\mathrm{Bw}$ & $0.22-0.40$ & 10 YR 7/4 & 10 YR 5/2 & gscl & \begin{tabular}{|l|l|}
$\mathrm{f}$ & 1 \\
\end{tabular} & sbk & sh & $\mathrm{fr}$ & sssp & ev & $\mathrm{c}$ & $\mathrm{s}$ & - & - & \begin{tabular}{|l|l}
- & - \\
\end{tabular} & -- & - & \\
\hline $\mathrm{BC}$ & 0.40 & \multicolumn{17}{|c|}{ Gravel bed } \\
\hline Pedon 7 & \multicolumn{17}{|c|}{ Lithic Haplustalf (Upland), $1^{\circ} 59^{\prime} 33.7^{\prime \prime} \mathrm{N} 7^{\circ} 23^{\prime} 33.7^{\prime \prime} \mathrm{E}, 433 \mathrm{~m}$ (MSL), 1-3 \% slope } & \\
\hline Ap & $0.00-0.19$ & 7.5 YR 5/6 & $7.5 \mathrm{YR} 3 / 4$ & gsl & \begin{tabular}{l|l|l}
$\mathrm{f}$ & 1 \\
\end{tabular} & $\mathrm{cr}$ & sh & fr & sssp & - & $\mathrm{d}$ & $\mathrm{W}$ & - & - & - & $-\mathrm{f}^{-} \mathrm{f}$ & $\mathrm{f}$ & \\
\hline $\mathrm{Bt}$ & $0.19-0.40$ & 7.5 YR 4/4 & $7.5 \mathrm{YR} 3 / 2$ & gscl & \begin{tabular}{l|l}
$\mathrm{f}$ & 1 \\
\end{tabular} & sbk & sh & fr & sssp & - & $\mathrm{d}$ & $\mathrm{w}$ & $\mathrm{t}$ & tn & 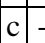 & -- & - & \\
\hline $\mathrm{R}$ & 0.40 & \multicolumn{17}{|c|}{ Hard granite-gneiss } \\
\hline Pedon 8 & \multicolumn{17}{|c|}{ Lithic Ustorthent (Upland), $1^{\circ} 00^{\prime} 04.9^{\prime \prime} \mathrm{N} 77^{\circ} 22^{\prime} 16.5^{\prime \prime} \mathrm{E}, 456 \mathrm{~m}$ (MSL), 1-3 \% slope } & \\
\hline Ap & $0.00-0.20$ & 7.5 YR 5/8 & $7.5 \mathrm{YR} 4 / 6$ & gls & \begin{tabular}{|l|l}
$\mathrm{f}$ & 1 \\
\end{tabular} & $\mathrm{sg}$ & 1 & $\mathrm{fr}$ & $\mathrm{sp}_{0}$ & - & $\mathrm{c}$ & $\mathrm{s}$ & - & - & - & $-\mathrm{f}$ & $\mathrm{f}$ & \\
\hline $\mathrm{AC}$ & $0.21-0.45$ & 7.5 YR 4/4 & 7.5 YR 3/3 & gls & \begin{tabular}{l|l|}
$\mathrm{f}$ & 1 \\
\end{tabular} & $\mathrm{sg}$ & 1 & $\mathrm{fr}$ & $\mathrm{sp}_{0}$ & - & $\mathrm{c}$ & $\mathrm{s}$ & - & - & - & -- & - & \\
\hline $\mathrm{Cr}$ & 0.45 & \multicolumn{17}{|c|}{ Weathered gneiss } \\
\hline Pedon9 & \multicolumn{18}{|c|}{ Lithic Ustorthent (Upland), $14^{\circ} 58^{\prime} 09^{\prime \prime}{ }^{\prime \prime} \mathrm{N} 77^{\circ} 25^{\prime} 51.5^{\prime \prime} \mathrm{E}, 410 \mathrm{~m}$ (MSL), 15-35 \% slope } \\
\hline $\mathrm{A}$ & $0.00-0.20$ & $7.5 \mathrm{YR} 4 / 6$ & $7.5 \mathrm{YR} \mathrm{3/3}$ & gsl & \begin{tabular}{l|l}
$\mathrm{f}$ & 1 \\
\end{tabular} & sbk & sh & fr & sssp & -1 & $\mathrm{c}$ & $\mathrm{s}$ & - & -1 & $-1-$ & $--_{-1}^{-f}$ & $\mathrm{f}$ & \\
\hline $\mathrm{R}$ & 0.20 & \multicolumn{17}{|c|}{ Hard granite gneiss } \\
\hline
\end{tabular}

Texture : c - clay, cl - clay loam, 1 - loam, s - sand, sl - sandy loam, scl - sandy clay loam, sc - sandy clay, ls - loamy sand

Structure : Size (S) - vf - very fine, f - fine, $\mathrm{m}$ - medium, c - coarse; Grade (G) - 0 - structureless, 1 - weak, 2 - moderate, 3 - strong;

Type (T) cr - crumb, sg - single grain, abk - angular blocky,sbk - sub-angular blocky.

Consistence:

Dry : s - soft, 1 - loose, sh - slightly hard, h - hard, vh - very hard, eh - extremely hard

Moist : 1 - loose, fr - friable, fi - firm, vfi - very firm, efi - extremely firm

Wet : $\mathrm{s}_{0}$ - non-sticky, ss - slightly sticky, s - sticky, vs - very sticky; $\mathrm{p}_{0}$ - non-plastic, ps - slightly plastic, $\mathrm{p}$ - plastic, vp - very plastic

Cutans : Ty - type - t - Argillan, Th - Thickness, tn - thin, th - thick, Quantity (Q), p - patchy, $\mathrm{c}$ - continuous

Pores : Size (S) f - fine, $\mathrm{m}$ - medium, c- coarse; $\mathrm{Q}$ - Quantity, f - few, c - common, $\mathrm{m}$ - many

Roots : Size (S) f - fine, m- medium, c- coarse; Q - Quantity, f - few, c - common, $\mathrm{m}$ - many

Effervescence : es - strong effervescence, ev - violent effervescence

Boundary : D - Distinctness, $\mathrm{c}$ - clear, $\mathrm{g}$ - gradual, $\mathrm{d}$ - diffuse, $\mathrm{T}$ - Topography; $\mathrm{s}$ - smooth; $\mathrm{w}$ - wavy 
Table 2: Physical characteristics of the soils

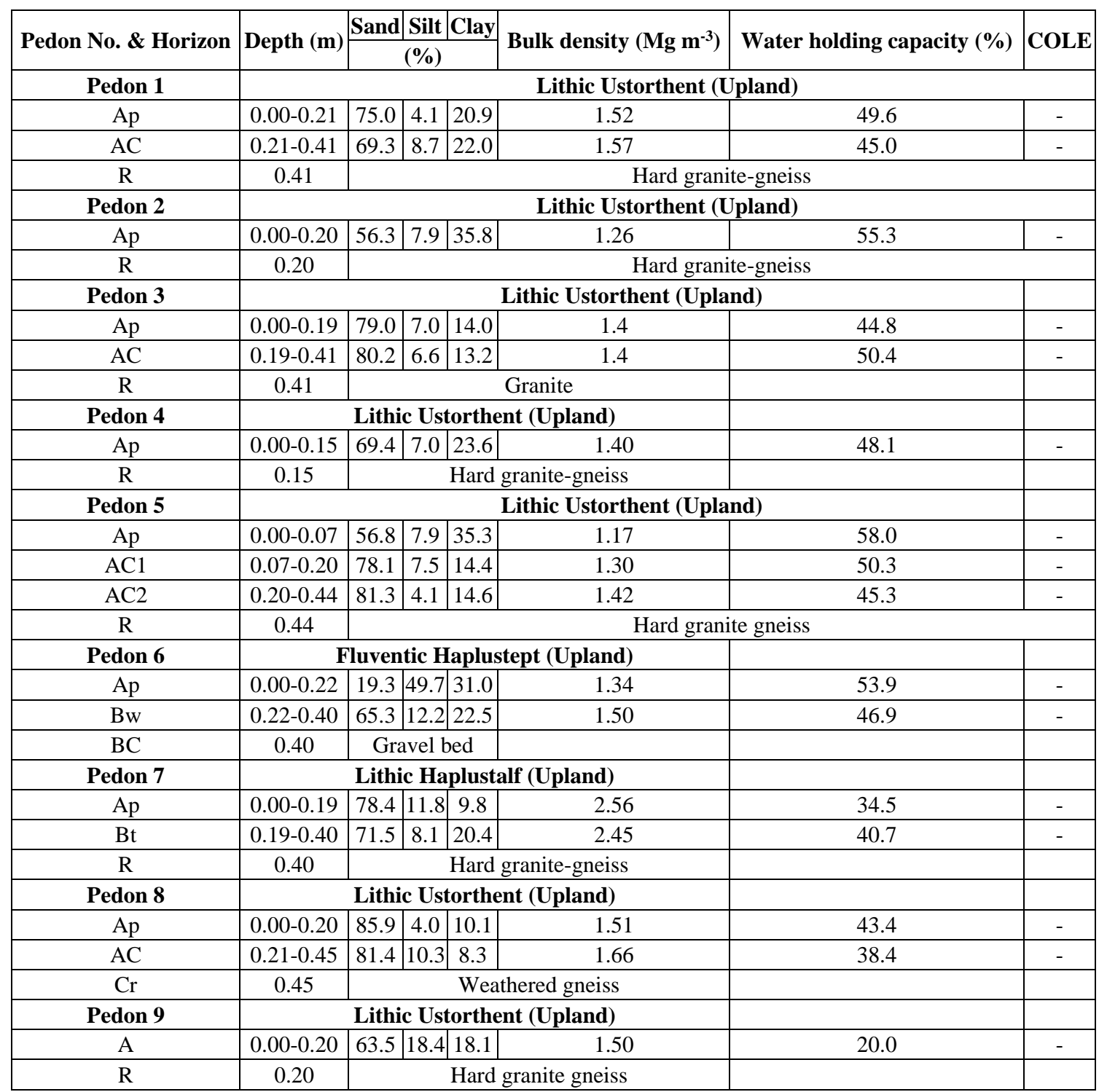

Table 3: Chemical properties of the soils

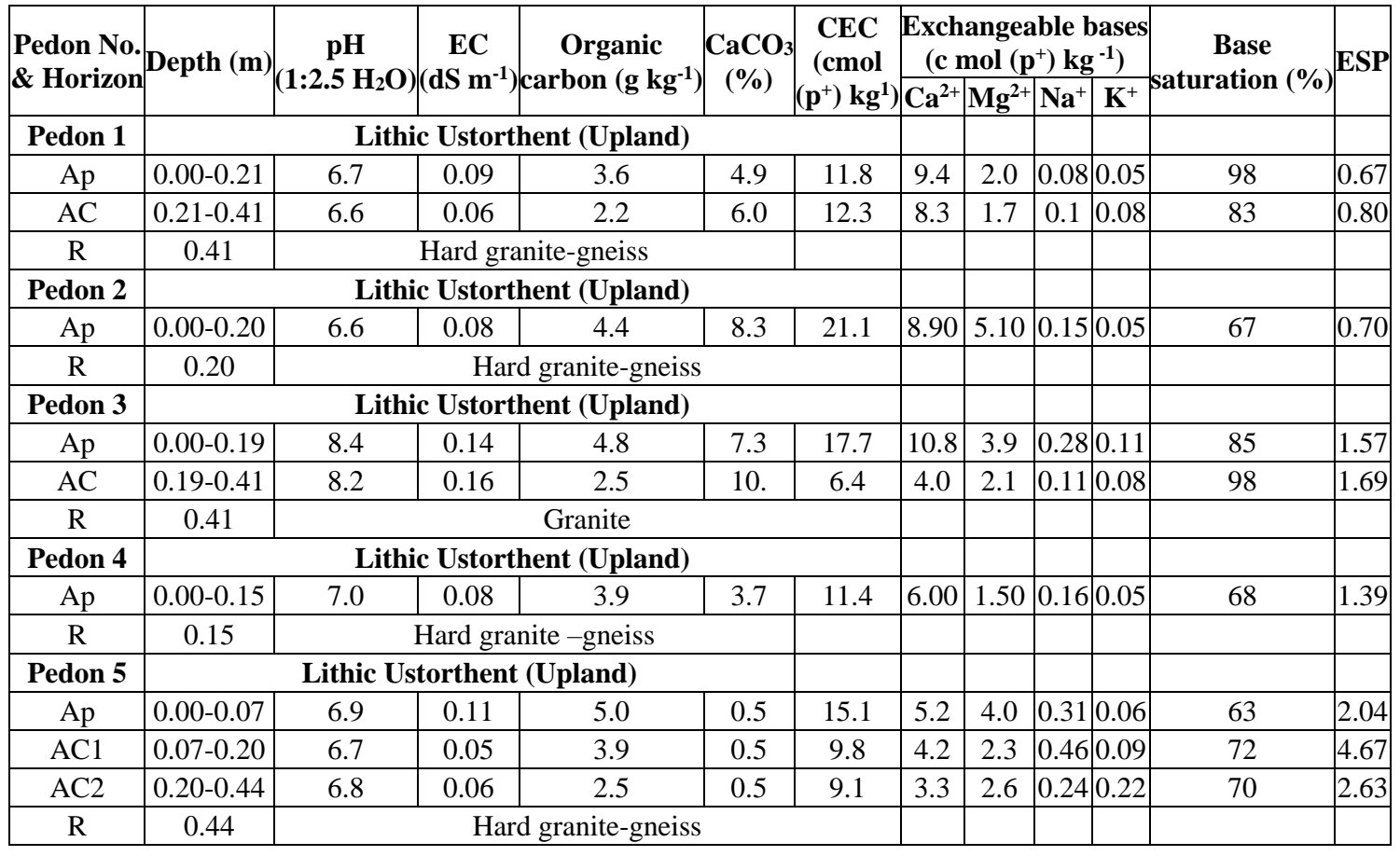




\begin{tabular}{|c|c|c|c|c|c|c|c|c|c|c|c|c|}
\hline \multirow[t]{2}{*}{$\begin{array}{l}\text { Pedon No. } \\
\text { \& Horizon }\end{array}$} & \multirow[t]{2}{*}{ Depth (m) } & \multirow[t]{2}{*}{$\begin{array}{c}\mathrm{pH} \\
\left(1: 2.5 \mathrm{H}_{2} \mathrm{O}\right)\end{array}$} & \multirow[t]{2}{*}{$\begin{array}{c}\mathrm{EC} \\
\left(\mathrm{dS} \mathbf{~ m}^{-1}\right)\end{array}$} & \multirow[t]{2}{*}{$\begin{array}{c}\text { Organic } \\
\text { carbon }\left(\mathrm{g} \mathrm{kg}^{-1}\right)\end{array}$} & \multirow{2}{*}{$\underset{(\%)}{\mathrm{CaCO}_{3}}$} & \multirow{2}{*}{$\begin{array}{c}\mathrm{CEC} \\
(\mathrm{cmol} \\
\left.\left(\mathrm{p}^{+}\right) \mathrm{kg}^{\mathbf{1}}\right)\end{array}$} & \multicolumn{4}{|c|}{$\begin{array}{c}\text { Exchangeable bases } \\
\left(\mathrm{c} \mathrm{mol}\left(\mathrm{p}^{+}\right) \mathrm{kg}^{-1}\right)\end{array}$} & \multirow[t]{2}{*}{$\begin{array}{c}\text { Base } \\
\text { saturation (\%) }\end{array}$} & \multirow[t]{2}{*}{ ESP } \\
\hline & & & & & & & $\mathrm{Ca}^{2+}$ & $\mathrm{Mg}^{2+}$ & $\mathbf{N a}^{+}$ & $\mathbf{K}^{+}$ & & \\
\hline Pedon 6 & \multicolumn{6}{|c|}{ Typic Haplustept (Upland) } & & & & & & \\
\hline Ap & $0.00-0.22$ & 8.2 & 0.06 & 5.5 & 17.3 & 14.7 & 7.2 & 4.7 & 0.52 & 0.21 & 86 & 3.53 \\
\hline $\mathrm{Bw}$ & $0.22-0.40$ & 8.3 & 0.20 & 2.0 & 15.5 & 13.3 & 8.8 & 2.8 & 0.48 & 0.36 & 94 & 3.59 \\
\hline $\mathrm{BC}$ & 0.40 & \multicolumn{5}{|c|}{ Gravel bed } & & & & & & \\
\hline Pedon 7 & \multicolumn{6}{|c|}{ Lithic Haplustalf (Upland) } & & & & & & \\
\hline Ap & $0.00-0.19$ & 7.9 & 0.16 & 4.8 & 1.0 & 11.0 & 4.2 & 3.0 & 0.4 & 0.20 & 71 & 3.61 \\
\hline $\mathrm{Bt}$ & $0.19-0.40$ & 7.5 & 0.02 & 1.8 & 2.6 & 19.1 & 6.6 & 3.1 & 0.77 & 0.10 & 55 & 4.03 \\
\hline $\mathrm{R}$ & 0.40 & \multicolumn{5}{|c|}{ Hard granite-gneiss } & & & & & & \\
\hline Pedon 8 & \multicolumn{6}{|c|}{ Lithic Ustorthent (Upland) } & & & & & & \\
\hline $\mathrm{Ap}$ & $0.00-0.20$ & 6.7 & 0.03 & 4.6 & 1.6 & 11.8 & 6.2 & 3.5 & 0.25 & 0.13 & 85 & 2.11 \\
\hline $\mathrm{AC}$ & $0.21-0.45$ & 6.6 & 0.03 & 1.0 & 0.5 & 9.5 & 5.3 & 1.1 & 0.22 & 0.13 & 71 & 2.30 \\
\hline $\mathrm{Cr}$ & 0.45 & \multicolumn{4}{|c|}{ Weathered gneiss } & & & & & & & \\
\hline Pedon 9 & \multicolumn{5}{|c|}{ Lithic Ustorthent (Upland) } & & & & & & & \\
\hline $\mathrm{A}$ & $0.00-0.20$ & 7.1 & 0.15 & 4.6 & 2.4 & 7.6 & 4.26 & 2.1 & 0.50 & 0.40 & 96 & 6.52 \\
\hline $\mathrm{R}$ & 0.20 & \multicolumn{3}{|c|}{ Hard granite-gneiss } & & & & & & & & \\
\hline
\end{tabular}

Table 4: Available nutrient status of the soils

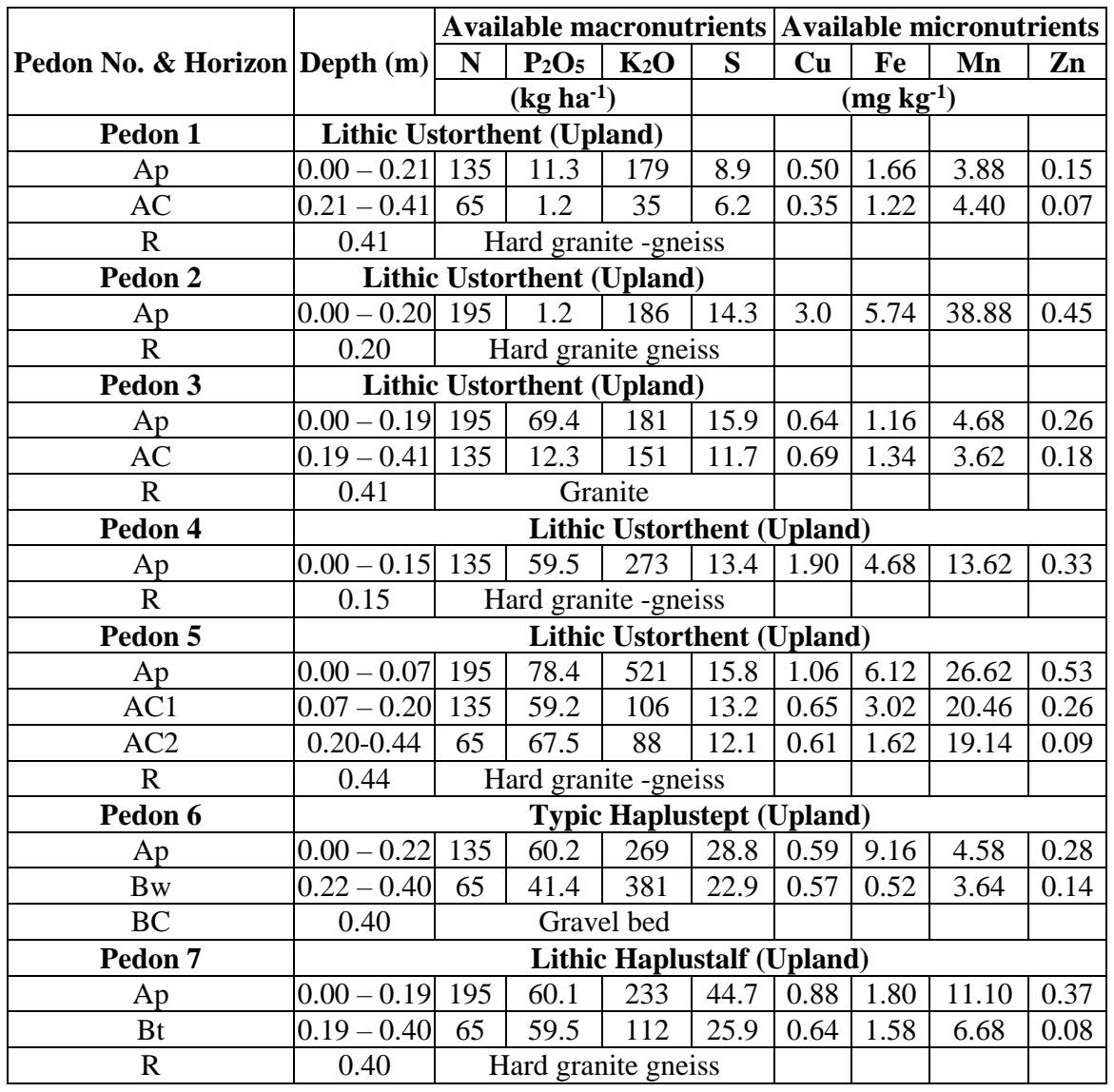

\begin{tabular}{|c|c|c|c|c|c|c|c|c|c|}
\hline Pedon 8 & \multicolumn{9}{|c|}{ Lithic Ustorthent (Plains) } \\
\hline Ap & $0.00-0.20$ & 195 & 77.9 & 169 & 23.2 & 0.57 & 22.04 & 20.36 & 0.23 \\
\hline $\mathrm{AC}$ & $0.21-0.45$ & 65 & 1.2 & 162 & 13.1 & 0.99 & 11.74 & 13.70 & 0.12 \\
\hline $\mathrm{Cr}$ & 0.45 & & Neathe & d gnei & & & & & \\
\hline Pedon 9 & \\
\hline $\mathrm{A}$ & $0.00-0.20$ & 64 & 34.8 & 135 & 11.5 & 0.25 & 3.16 & 4.88 & 0.54 \\
\hline $\mathbf{R}$ & 0.20 & & & e gn & & & & & \\
\hline
\end{tabular}




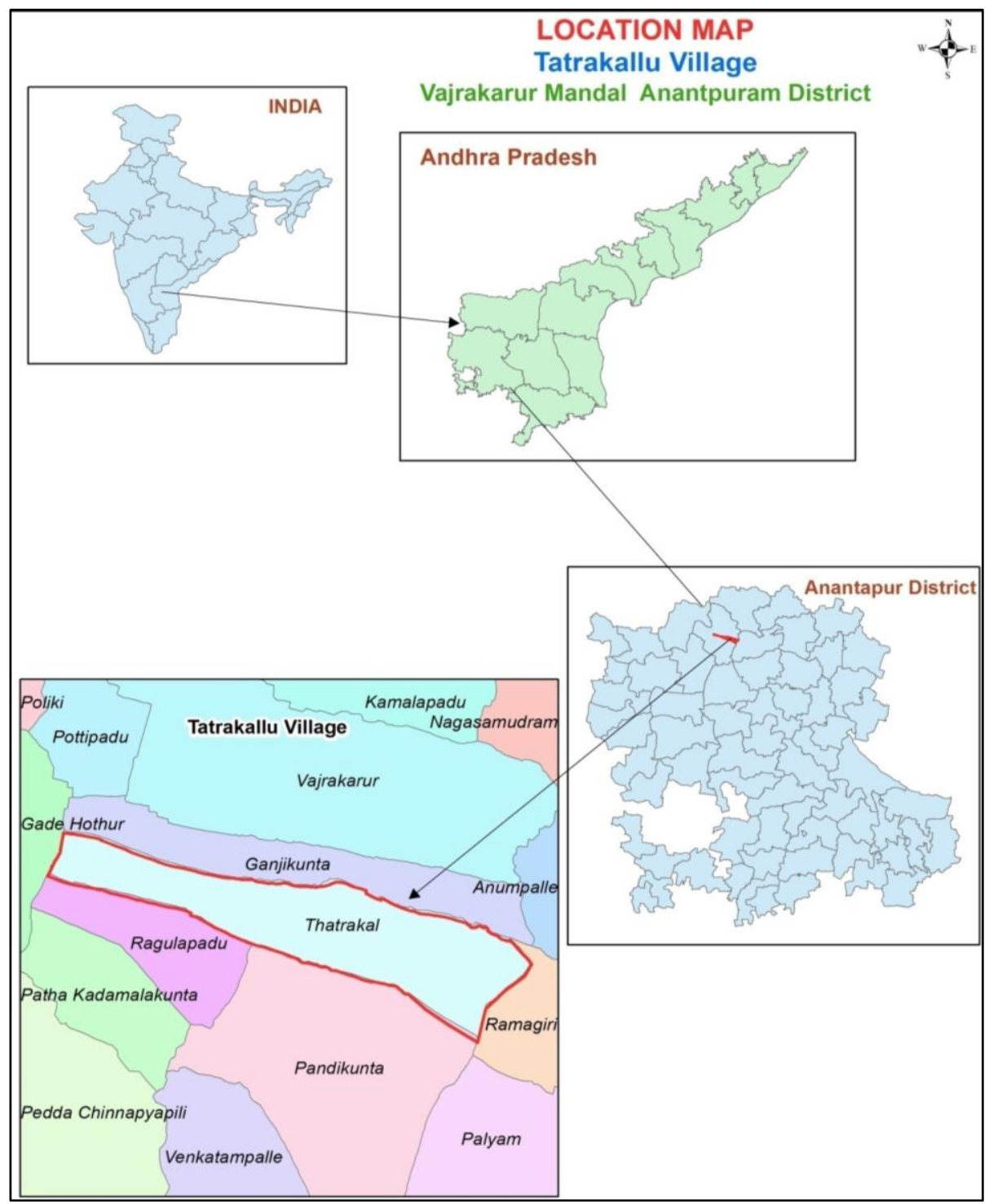

Fig 1: Location map of Tatrakallu village

\section{Conclusion}

The morphological, physical and chemical properties of Tatrakallu village of Anantapuramu district of Andhra Pradesh revealed that the soils were neutral to strongly alkaline in reaction, nonsaline and low to medium in OC content. The $\mathrm{CEC}$ values were low to medium and exchange complex was dominated by $\mathrm{Ca}^{2+}$ followed by $\mathrm{Mg}^{2+}, \mathrm{Na}^{+}$and $\mathrm{K}^{+}$ions. The soils were low in available nitrogen, low to high in available phosphorous and potassium, deficient to sufficient in available sulphur, deficient to sufficient in DTPA extractable $\mathrm{Zn}, \mathrm{Fe}$ and $\mathrm{Mn}$ and sufficient in DTPA extractable $\mathrm{Cu}$. However, Entisols consisting of Typic Ustifluvents and Lithic Ustorthents, Inceptiols such as Lithic Haplustepts, Typic Haplustepts and Fluventic Haplustepts and Alfisols like Lithic Haplustalfs and Tpic Haplustalfs were occupied uplands. Furthermore, the study revealed considerable variations in morphological, physical and chemical properties of soils as they were developed from different parent materials and landforms. The main constraints found in uplands were shallow depth, sloppiness, excessively drained and poor water holding capacity. The suggested measures were adoption of contour bunding and contour farming and mixing of top soil with tank silt, deep ploughing and adoption of green manuring with dhaincha and its incorporation before sowing of next crop.

\section{Acknowledgment}

The senior author is highly grateful to the Acharya N.G. Ranga Agricultural University, Guntur, Andhra Pradesh for providing financial assistance in the form of stipend during course of investigation.

\section{References}

1. AIS\&LUS Soil Survey Manual, All India Soil and Land Use Survey Organization, IARI, New Delhi, 1970, 1-63.

2. APSAC. District Survey report- Anantapuramu district. Andhra Pradesh Space Application centre, Vijayawada, 2018.

3. Devi, PAV, Naidu MVS, Ramakrishnarao A. Characterization and classification of sugarcane growing soils in southern agro-climatic zone: A Case study in eastern mandals of Chittoor District in Andhra Pradesh. J Ind. Soc. Soil Sci. 2015; 63(3):245-258.

4. Jackson ML. Soil Chemical Analysis. Prentice Hall of India (Pvt.) Ltd., New Delhi, 1973.

5. Kumar YSS, Naidu MVS. Characteristics and classification of soils representing major landforms in Vadamalapeta mandal of Chittoor district, Andhra Pradesh. J Ind. Soc. Soil Sci. 2012; 60(1):63-67.

6. Lindsay WL, Norvell WA. Development of DTPA soil test for zinc, iron, manganese and copper. Soil Sci. Soc. Ameri J. 1978; 43:421-428. 
7. Naidu LGK, Hegde R, Ramamurthy V, Thayalan S, Srinivas S, Niranjana KV. Soil resource of Anantapur district, Andhra Pradesh. NBSS report No. 1017. National Bureau of Soil Survey and Land use Planning, Bangalore, 2008.

8. Rao APVP, Naidu MVS, Ramavatharam N, Rama Rao G. Characterization, classification and evaluation of different landforms in Ramchandrapuram mandal of Chittoor district in Andhra Pradesh for sustainable land use planning. J Ind. Soc. Soil Sci. 2008; 56(1):23-33.

9. Reddy KS, Naidu MVS. Characterization and classification of soils in semi-arid region of Chennur mandal in Kadapa district, Andhra Pradesh. J Ind. Soc. Soil Sci. 2016; 64(3):207-217.

10. Sarkar D, Baruah U, Gangopadhyay SK, Sahoo AK, Velayutham M. Characteristics and classification of soils of Loktak catchment area of Manipur for sustainable land use planning. J Ind. Soc. Soil Sci. 2002; 50(2):196-204.

11. Satish S, Naidu MVS, Ramana KV, Munaswamy V, Reddy GP, Sudhakar P. Characterization and classification of the soils of Brahmanakotkur watershed in Kurnool district of Andhra Pradesh. J Ind. Soc. Soil Sci. 2018; 66(4):35-361.

12. Sahrawat KL. Phosphate sorption in benchmark Vertisol and Alfisol profiles. J Ind. Soc. Soil Sci. 1999; 47:144146.

13. Sekhar CCh, Balaguruvaiah D, Naidu MVS. Studies on genesis, characterization and classification of soils in central and Eastern parts of Pakasam district in Andhra Pradesh. Agropedology. 2014; 24(2):125-137.

14. Sharma RC, Mandal A, Singh R, Singh YP. Characteristics and use potential of sodic and associated soils in CSSRI experimental farm, Lucknow, Uttar Pradesh. J Ind. Soc. Soil Sci. 2011; 59(4):381-387.

15. Sharma SP, Sharma PD, Singh SP, Minhas RS. Characterization of Soan river valley soils in lower Siwaliks of Himachal Pradesh-II. Piedmont and flood plain soils. J Ind. Soc. Soil Sci. 1994; 42:105-110.

16. Sharma SS, Totawat KL, Shyampura RL. Characterization and classification of salt-affected soils of southern Rajasthan. J Ind. Soc. Soil Sci. 2004; 52:209213.

17. Singh IS, Agrawal HP. Characterisation, genesis and classification of rice soils of eastern region of Varnasi, Uttar Pradesh. Agropedology. 2004; 15:29-38.

18. Sireesha PVG, Naidu MVS. Studies on genesis, characterization and classification of soils in semi-arid Agro-ecological region: A case study in Banaganapalle mandal of Kurnool district, Andhra Pradesh. J Ind. Soc. Soil Sci. 2013; 61(3):167-178.

19. Soil Survey Division Staff. Soil Survey Manual (Indian print). USDA Hand book No. 18, US Govt. Printing office, Washington, DC, 2015.

20. Soil Survey Staff. Keys to Soil Taxonomy (Twelveth edition), USDA, Natural Resource Conservation Service, Washington, DC, 2014.

21. Thangasamy A, Naidu MVS, Ramavatharam N, Reddy CR. Characterization, classification and evaluation of soil resources in Sivagiri micro-watershed of Chittoor district in Andhra Pradesh for sustainable land use planning. J Ind. Soc. Soil Sci. 2005; 53:11-21.

22. Vedadri U, Naidu MVS. Characterization, classification and evaluation of soils in semi-arid ecosystem of Chillakur mandal in SPSR Nellore district of Andhra Pradesh. J Ind. Soc. Soil Sci. 2018; 66(1):9-19. 